\title{
First report of the nematode Leidynema appendiculata from Periplaneta fuliginosa
}

\author{
Sota Ozawa', Cláudia S. L. Vicente ${ }^{1,2}$, Kazuki Sato ${ }^{3}$, Toyoshi Yoshiga ${ }^{4}$, \\ Natsumi Kanzaki ${ }^{5}$ and Koichi Hasegawa ${ }^{1 *}$
}

\begin{abstract}
${ }^{1}$ Department of Environmental Biology, College of Bioscience \& Biotechnology, Chubu University. 1200 Matsumoto, Kasugai, Aichi 487-8501 Japan; ${ }^{2}$ ICAAM - Instituto de Ciências Agrárias e Ambientais Mediterrânicas, Departamento de Biologia, Universidade de Évora, Núcleo da Mitra, Ap. 94, 7002-554 Évora, Portugal; ${ }^{3}$ Laboratory of Terrestrial Microbial Ecology, Graduate School of Agriculture, Kyoto University, Sakyo, Kyoto, 606-8502 Japan; ${ }^{4}$ Laboratory of Nematology, Department of Applied Biological Sciences, Faculty of Agriculture, Saga University. Saga, 840-8502 Japan;

${ }^{5}$ Forest Pathology Laboratory, Forestry and Forest Products Research Institute, 1 Matsunosato, Tsukuba, Ibaraki 305-8687 Japan
\end{abstract}

\begin{abstract}
The smokybrown cockroach Periplaneta fuliginosa has spread all over the world, and is now one of the most undesired invasive alien pests in Japan. Because cockroaches are generally infected by thelastomatid nematodes, they are being distributed around the world with their parasitic nematodes. Nothing is known about parasitic nematode species in $P$. fuliginosa differences, or similarity of the parasite's population structures between the different countries of the host cockroaches. Here we investigated the P. fuliginosa invasive to Japan and found that $100 \%$ of individuals were infected with one nematode species. According to the morphology and the sequence of the D2/D3 expansion segment of the 28S ribosomal RNA gene, we identified the parasite as Leidynema appendiculata. This nematode reproduced by haplodiploidy and its developmental timing under various conditions is quite divergent. Their population in the hindgut of $P$. fuliginosa was controlled with a few adult females and a male. This is the first report of the thelastomatid nematode isolated from the smokybrown cockroach, and is the basis for our future research examining the origin, distribution route and immigration history of the cockroach and the impact of L. appendiculata on native Japanese cockroach species.
\end{abstract}

\section{Keywords}

Smokybrown cockroach, Periplaneta fuliginosa, invasive alien species, sanitary pest, Japan, Leidynema appendiculata

\section{Introduction}

Cockroaches are unique organisms in terms of environmental conditions. They can be found everywhere, in almost all habitats from tropical and temperate forests, such as grasslands, steppe, coastal communities, and even deserts (Bell et al. 2007). Because they have survived since the Carboniferous period (ca. 350 million years ago) without drastic change in their form, they are considered one of the most successful animal groups on earth and are able to cope with harsh climate change and survival competition (Grimaldi and Engel 2005). Although more than four thousand species have been identified worldwide (Bell et al. 2007), with 52 species in Japan (Asahina 1991), only a few of them, mainly the smokybrown cockroach Periplaneta fuliginosa, American cockroach P. americana and German cockroach Blattella germanica, are well known as sanitary pests (Ogata et al. 1975; Lee and Lee
2000; Miller and Meek 2004). They have also shown surprisingly high adaptiveness in changing their sensory behavior to reject man-made toxic baits (Wada-Katsumata et al. 2013). P. fuliginosa is thought to have originated in southern China, and is now distributed as an invasive species in Asia, Europe, Australia, and North and South America. Many successive authors have misidentified this species, for which the historical spread and distribution is still a mystery (Appel and Smith 2002). The Japanese native cockroach (P. japonica), once the most common domestic pest in Japan, has now been displaced to the outdoors and replaced by $P$. fuliginosa.

The oxyurid parasitic nematodes have been reported from many species of cockroaches; they seem to be a very old parasitic partner and commonly inhabit in the hindgut of their host and reproduce by haplodiploidy (Ainsworth 1991; Adamson 1994). Eggs laid by adult females, are deposited within their host feces and released by defecation. New host individ- 
uals are infected orally. Several parasitic nematode species sometimes co-infect individual cockroaches; for example, nematodes isolated from American cockroaches settling in several countries were Thelastoma bulhoesi, T. periplaneticola, Hammerschmidtiella diesingi, Leidynema appendiculata (Ozawa and Hasegawa unpublished data; Chitwood 1932; Dobrovolny and Ackert 1934; Adamson and Noble 1993; Connor and Adamson 1998; Shah 2007; Blanco et al. 2012). Therefore, these cockroaches have been moved globally with the help of humans along with their nematode parasites.

Because there is no report about the associated nematodes in the smokybrown cockroach, we surveyed P. fuliginosa in Japan for its nematode associates. We examined the nematode population of the host cockroach that will be the basis for our next study about mechanisms and evolution of the host-parasite interaction. In addition, embryo is the only stage to leave from its host during the life cycle of the thelastomatid nematodes. In order to understand the mode of their reproduction and whole picture of the nematode life cycle, we also observed the embryogenesis from the one-cell stage until the L2 stage.

\section{Materials and Methods}

\section{Cockroach strain and rearing}

Four strains of $P$. fuliginos $a$ CU, IK, FE, EE were used in this experiment (CU: Kasugai, Aichi Prefecture, Japan; IK, Chiba, Chiba Prefecture, Japan; FE: Shizuoka, Shizuoka Prefecture, Japan; EE: Ako, Hyogo Prefecture, Japan). The three strains IK, FE and EE were supplied by the Ikari Corporation, the Fuji Environmental Service, and the Earth Environmental Service, respectively. These strains have been collected and reared independently as laboratory strains, but detailed collection information is not known. Three adulthood females of P. fuliginosa were collected directly by hand at the Kasugai campus of Chubu University during September to October 2012, and established the CU strain. Cockroaches were reared in plastic cages $(30 \times 44 \times 32 \mathrm{~cm})$, fed on primate diet PS-A (contents were flour, corn, defatted soybean, white fish meal, peanut meal, rice flour) (Oriental Yeast CO. LTD, Tokyo) and water, and kept dark at around $28^{\circ} \mathrm{C}$ to observe the nematode prevalence in each developmental stage of the host insect.

\section{Nematode observation}

The legs and wings were removed from live adult cockroaches before being placed in a Syracuse watch glasses containing cockroach Ringer solution (Bell et al. 1981) and dissected. The hindgut was extracted and split longitudinally with tweezers to release nematodes. Nematodes were picked with a mouth pipette, transferred onto an agar pad (Shaham 2006), covered and sealed with a silicon grease-rimmed coverslip for viewing by Nomarski DIC optics. Although nematodes could be observed with high resolution, the nematode body width was deformed by coverslip pressure. To analyze nematode morphometrics, about $250 \mu \mathrm{m}$-thickness agar pads with a hole in the center were prepared. Living nematodes were transferred with a mouth pipette into the hole, gently heat-killed, covered with coverslips and measured by micrometer (Fig. 1).

\section{Molecular phylogenetic analysis}

Genomic DNA was extracted from individual adult nematodes with Qiagen DNeasy Blood \& Tissue Kit (Qiagen, USA). The D2/D3 expansion segment of 28S ribosomal RNA gene (D2/D3 LSU) was amplified using the universal primers D2a 5'- ACA AGT ACC GTG AGG GAAAGT TG -3' and D3b 5'TCG GAA GGA ACC AGC TAC TA -3' (Nunn 1992). The

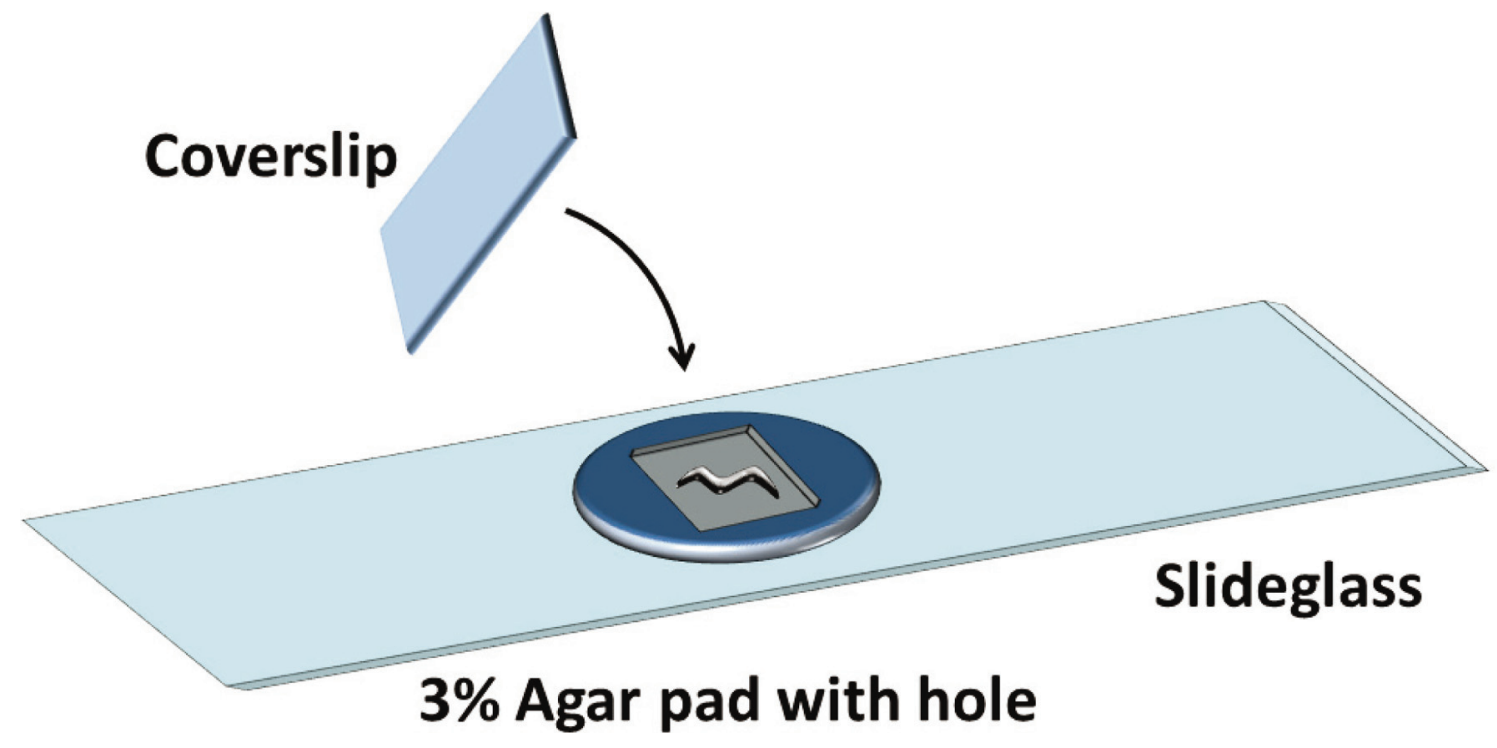

Fig. 1. Agar pad with a hole for morphometric analysis 
amplified DNA fragment was purified with the Wizard SV Gel and PCR clean-up system (Promega, USA), and sequenced using the ABI Prism BigDye terminator cycle sequencing Kit and analyzed on an ABI3130xl sequencer (ABI, USA).

A sequence of the D2/D3 segment was submitted to BLASTN search (NCBI, National Centre of Biotechnology and Information, http://www.ncbi.nlm.nih.gov/) for significant nucleotide sequence alignments and to GenBank for assignment of an accession number. For the phylogenetic analysis, the following sequences from the Thelastomatidae were selected: Leidynema appendiculata JQ343844, L. appendiculata EU365630, L. portentosae GQ401114, Cranifera cranifera EU365632, Hammerschmidtiella cristata EU365629, H. diesingi JQ343843, H. diesingi EU365628, Thelastoma sp. JQ343845 and Thelastoma sp. GQ368468. Ascaris lumbricoides AY210806 was selected as the out-group in the analysis. ClustalW multiple alignment was conducted in BioEdit version 5.0.9 (Hall 1999). Tree was constructed from evolutionary distances using the Neighbor-Joining method (Saitou and Nei 1987) and Kimura's two-parameter model (Kimura 1980) with a gamma distribution, using the Mega 5.0 software (Tamura et al. 2011). Phylogenetic robustness was inferred by bootstrap analysis using 1,000 iterations (Felsenstein 1985).

\section{Embryogenesis observation}

For viewing nematode embryogenesis, we collected one-cell embryos by three methods. (1) In feces: fresh feces of cockroaches, within one hour after defecation, were collected and transferred into a Syracuse watch glass containing the cockroach Ringer solution. Cockroach feces were teased with probes to release nematode eggs. One-cell stage nematode embryos were picked with a mouth pipette under the stereomicroscope, and transferred onto an agar pad. A total of eight one-cell embryos were collected and observed at room temperature $\left(\mathrm{ca} .25^{\circ} \mathrm{C}\right)$ for every hour until the four-cell stage, and then every 24 hours until the L2 stage. (2) Ex uterus: About ten eggs were released from the vulva when a female nematode was harvested from the host cockroach and probed with a needle. Just-laid eggs were picked-up with a mouth pipette and transferred onto an agar pad. A total 10 one-cell embryos were collected and observed at room temperature for every hour until the four-cell stage, and then every 24 hours until the L2 stage. (3) In uterus: There are large numbers of shell-formed eggs in the female nematode uterus. Three adult females were transferred onto an agar pad and eggs in the uterus were observed at room temperature once per day (24 hour) until the L2 stage.

\section{Statistical analysis}

Descriptive analysis and statistical inference was conducted using software SPSS software. To assess statistical differences between cockroach developmental stages (adult female and male; last instar; and 1st to 5th larva) in relation to the number of adult female/male and juvenile nematodes, one-way ANOVA analysis was performed, followed by post hoc multiple mean comparison Tukey's HSD (honestly significant diferences) at 95\% significant level and using a harmonic mean sample size.

\section{Results}

\section{Morphological identification of the parasitic nematode}

The number of molts from the 1st instar to reach adults was 6 in $P$. fuliginosa in our laboratory reared conditions (Fig. 2). Total 120 smokybrown cockroaches from four independent culturing strains were dissected and checked for the existence of parasitic nematodes (Table I). All smokybrown cockroaches were infected with only one nematode species, identified as Leidynema appendiculata according with morphological characters described below and in Fig. 3, and in accordance with the previous reports (Dobrovolny and Ackert 1934; Adamson and van Waerebeke 1992; Shah 2007).

Adult female ( $\mathrm{N}=20)$, $\mathrm{L}$ (body length), $2575.0 \pm 314.6 \mu \mathrm{m}$ (1983.4-3225.0); a (body length/maximum body width), 10.7 $\pm 1.2 \mu \mathrm{m}$ (9.0-13.1); b (body length /oesophagus length), 6.2 $\pm 0.9 \mu \mathrm{m}$ (4.7-8.2); c (body length/tail length), $4.3 \pm 1.3 \mu \mathrm{m}$ (3.2-7.9); maximum body width, $242.4 \pm 37.3 \mu \mathrm{m}$ (190.0 325.0 ); buccal cavity length, $19.6 \pm 4.1 \mu \mathrm{m}(12.5-28.2)$; buccal cavity width, $9.0 \pm 2.0 \mu \mathrm{m}(5.7-13.3)$; oesophagus length, $415.7 \pm 19.9 \mu \mathrm{m}(360.0-451.4)$; corpus length, $267.6 \pm 22.3 \mu \mathrm{m}$ (210.0-314.3); isthmus length, $24.7 \pm 5.7 \mu \mathrm{m}$ (12.9-38.6); posterior bulb length, $106.7 \pm 8.1 \mu \mathrm{m}(88.6-124.5)$; posterior

Table I. Numbers of cockroach strains, sex and stages used in this experiment

\begin{tabular}{|c|c|c|c|c|c|c|c|c|c|}
\hline & Total & M & $\mathbf{F}$ & Last & 5th & 4th & 3rd & 2nd & $1 \mathrm{st}$ \\
\hline Total & 120 & 10 & 18 & 13 & 13 & 14 & 15 & 23 & 14 \\
\hline $\mathrm{CU}$ & 61 & 1 & 3 & 4 & 7 & 5 & 11 & 21 & 9 \\
\hline $\mathrm{EE}$ & 40 & 4 & 10 & 1 & 6 & 9 & 3 & 2 & 5 \\
\hline $\mathrm{FE}$ & 12 & 2 & 3 & 6 & 0 & 0 & 1 & 0 & 0 \\
\hline IK & 7 & 3 & 2 & 2 & 0 & 0 & 0 & 0 & 0 \\
\hline
\end{tabular}

M, adult male; F, adult female; Last, last (6th) instar; 5th to 1st, 5th to 1st instar. Difficult to distinguish male and female when cockroach was a larval stage. 


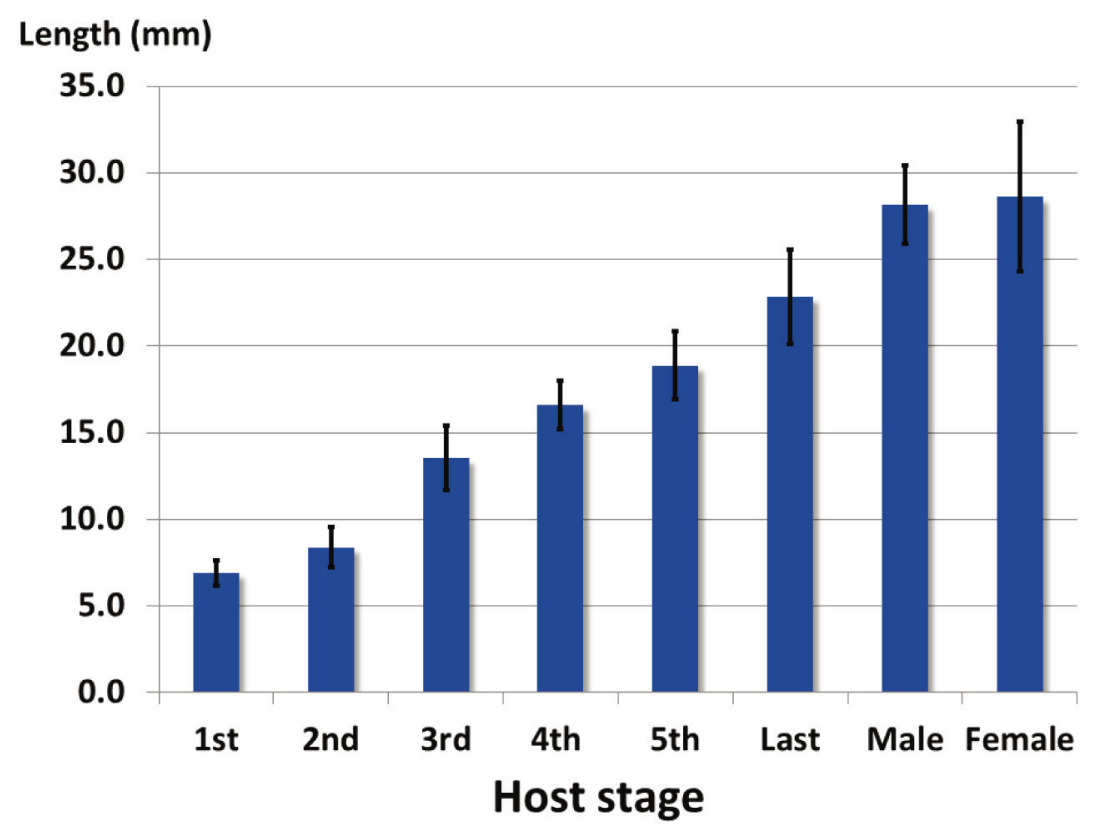

Fig. 2. Periplaneta fuliginosa average body lengths $(\mathrm{mm})$ in each developmental stage. The number of cockroaches used in this experiments were: adult male, 10; adult female, 18; last instar, 13; 5th instar, 13; 4th instar, 14; 3rd instar, 15; 2nd instar, 23; 1st instar, 14

bulb width, $118.0 \pm 11.4 \mu \mathrm{m}(101.4-147.7)$; nerve ring-anterior end, 163.6 $\pm 22.2 \mu \mathrm{m}$ (122.9-240.0); excretory pore-anterior end, $609.3 \pm 170.2 \mu \mathrm{m}(450.0-1216.5)$; vulva-anterior end, $1026.8 \pm 254.8 \mu \mathrm{m}(600.0-1471.4)$; tail length, $619.0 \pm$ $114.5 \mu \mathrm{m}(374.3-797.1)$.

Adult male $(\mathrm{N}=14)$, L (body length), $704.1 \pm 262.2 \mu \mathrm{m}$ (351.4-1230.0); a (body length/maximum body width), $12.4 \pm$ $2.4 \mu \mathrm{m}$ (9.0-16.4); b (body length /oesophagus length), $3.5 \pm$ $1.2 \mu \mathrm{m}$ (1.9-5.9); c (body length/tail length), $87.6 \pm 48.5 \mu \mathrm{m}$ (53.6-239.5); maximum body width, $55.9 \pm 14.6 \mu \mathrm{m}$ (31.476.5); Buccal cavity length, $14.6 \pm 2.1 \mu \mathrm{m}$ (10.8-17.4); Buccal cavity width, $6.3 \pm 0.9 \mu \mathrm{m}$ (4.3-7.5); Oesophagus length, $199.9 \pm 26.2 \mu \mathrm{m}$ (161.4-234.3); Corpus length, $122.1 \pm 22.7$ $\mu \mathrm{m}$ (81.0-151.1); Isthmus length, $22.5 \pm 5.5 \mu \mathrm{m}$ (11.6-34.0); Posterior bulb length, $45.9 \pm 6.7 \mu \mathrm{m}(34.0-54.8)$; Posterior bulb width, $42.0 \pm 5.3 \mu \mathrm{m}(32.4-49.0)$; Nerve ring-anterior end, $122.4 \pm 31.0 \mu \mathrm{m}(59.8-159.3)$; Excretory pore-anterior end, $284.2 \pm 71.3 \mu \mathrm{m}$ (175.1-430.0); Spicule length, $40.0 \pm$ $3.1 \mu \mathrm{m}(34.0-44.0)$; Tail length, $8.7 \pm 2.7 \mu \mathrm{m}(4.2-12.9)$.

Egg length $(\mathrm{N}=30), 114.8 \pm 6.5 \mu \mathrm{m}(102.9-125.7)$; Egg width $(\mathrm{N}=30), 43.0 \pm 2.0 \mu \mathrm{m}(40.0-47.1)$.

\section{Molecular identification of the parasitic nematode}

The D2/D3 expansion segment of the 28S ribosomal RNA gene ( $823 \mathrm{bp}$ ) was amplified from the nematode genome and deposited in the NCBI GenBank with accession number KC540759; its sequence was closest to the other isolates identified as L. appendiculata JQ343844 (702 identical bases per 714 bp, 2 bp gaps and 14 bp substitutions) and EU365630

Table II. Number (mean \pm SD) of Leidynema appendiculata in different host sexes and stage

\begin{tabular}{|c|c|c|c|c|}
\hline & $\mathbf{N}$ & Adult male & Adult female & Juvenile $^{2}$ \\
\hline Total & 120 & $1.0 \pm 1.1$ & $3.5 \pm 6.3$ & $4.8 \pm 7.0$ \\
\hline Adult male & 10 & $0.9 \pm 0.3 \mathrm{a}$ & $3.19 \pm 2.2 b$ & $3.9 \pm 6.0 \mathrm{bc}$ \\
\hline Last instar ${ }^{1}$ & 13 & $1.0 \pm 0.0 \mathrm{a}$ & $3.3 \pm 2.1 b$ & $4.2 \pm 6.7 b c$ \\
\hline 5 th instar ${ }^{1}$ & 13 & $1.1 \pm 0.3 \mathrm{a}$ & $3.6 \pm 2.3 b$ & $10.2 \pm 7.3 \mathrm{ab}$ \\
\hline 2nd instar ${ }^{1}$ & 23 & $0.8 \pm 0.4 \mathrm{a}$ & $1.1 \pm 1.5 b$ & $0.9 \pm 1.1 \mathrm{c}$ \\
\hline 1st instar ${ }^{1}$ & 14 & $0.6 \pm 0.5 \mathrm{a}$ & $0.7 \pm 0.5 b$ & $1.1 \pm 1.1 \mathrm{c}$ \\
\hline
\end{tabular}

${ }^{1}$ Difficult to distinguish male and female when cockroach was a larval stage. ${ }^{2}$ Difficult to distinguish male and female when nematode was a juvenile stage. Means with different letters in a column indicate statistically differences (Tukey's test, $\mathrm{p}<0.05$ ). 

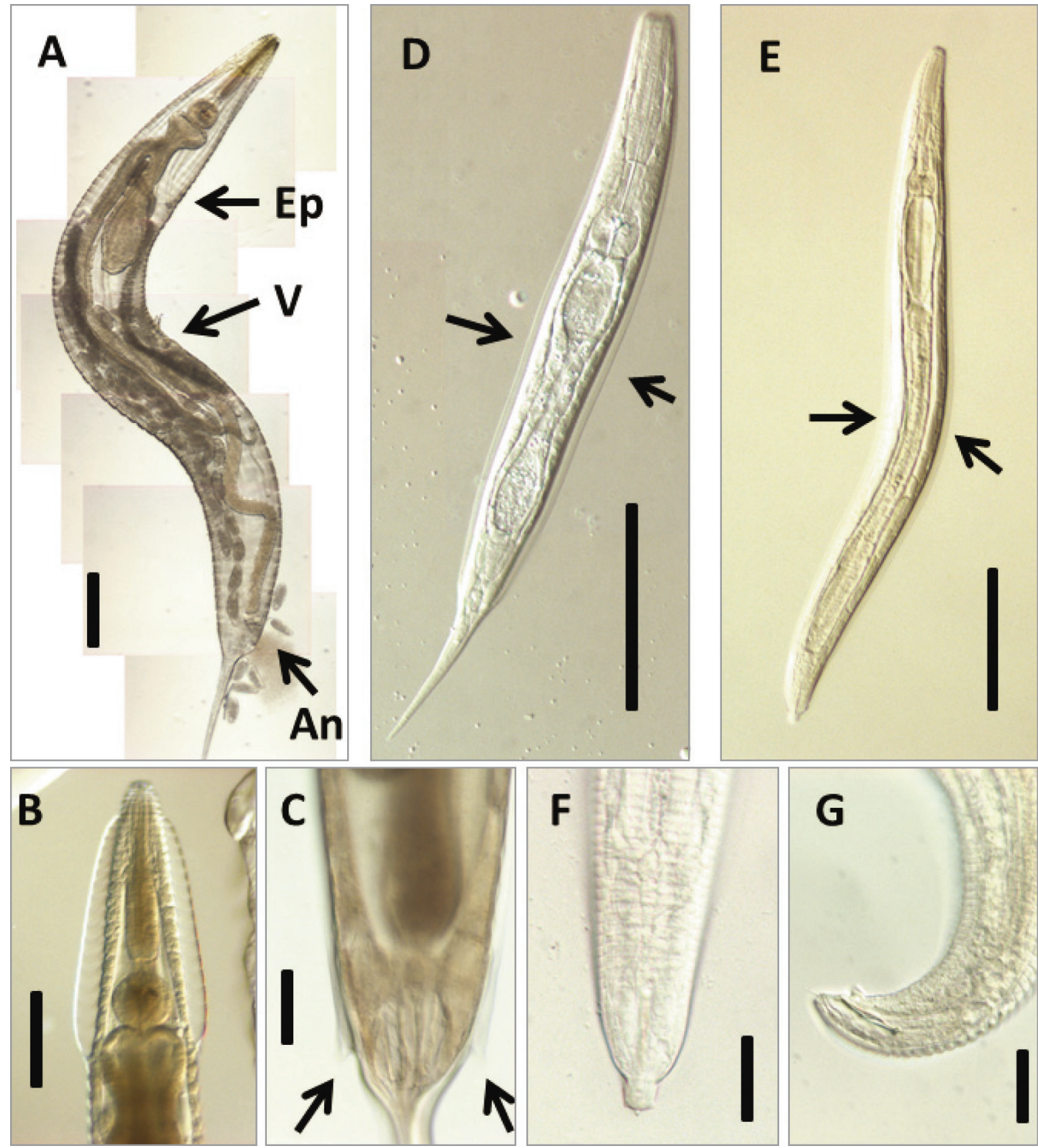

Fig. 3. Nomarski DIC image of L. appendiculata. (A) Adult female, right lateral view. Cylindrical and tapered shape toward both anteriorposterior ends. The corpus consists with anterior cylindrical part and posterior bulb. Alimentary system is divided to diverticulum and gut tube. Vulva is located at center but a little closer to the cephalic region. Ep, Excretory pore; V, vulva; An, anus. (B) Adult female head with prominent lateral allae, ventral view. Cephalic alae are prominent. (C) Adult female tail with lateral allae (arrows), ventral view. (D) Juvenile with lateral allae (arrows), ventral view. Lateral alae expand from cephalic to caudal region. (E) Adult male with lateral allae (arrows), ventral view. (F) Male tail, ventral view. Caudal tip has smaller tail with short terminal spine. Three pairs of caudal papillae present. (G) Male tail, left lateral view. Scale bars, (A), $200 \mu \mathrm{m}$; (B), (E), $100 \mu \mathrm{m}$; (C), (D), $50 \mu \mathrm{m}$; (F), (G), $20 \mu \mathrm{m}$

(702 identical bases per 714 bp, 3 bp gaps and 13 bp substitutions) with $98 \%$ similarity $(E$-value $=0.0)$. The NJ inferred tree for thelastomatid species is reported in Fig. 4, and our nematode sequences clustered near the other L. appendiculata isolates (JQ343844 and EU365630).
Population structure of L. appendiculata in different host sexes and stages.

We dissected 10 adult males, 18 adult females and 92 larvae of cockroaches, and counted the numbers of the nematodes that were adult males and females, and juveniles (Table 


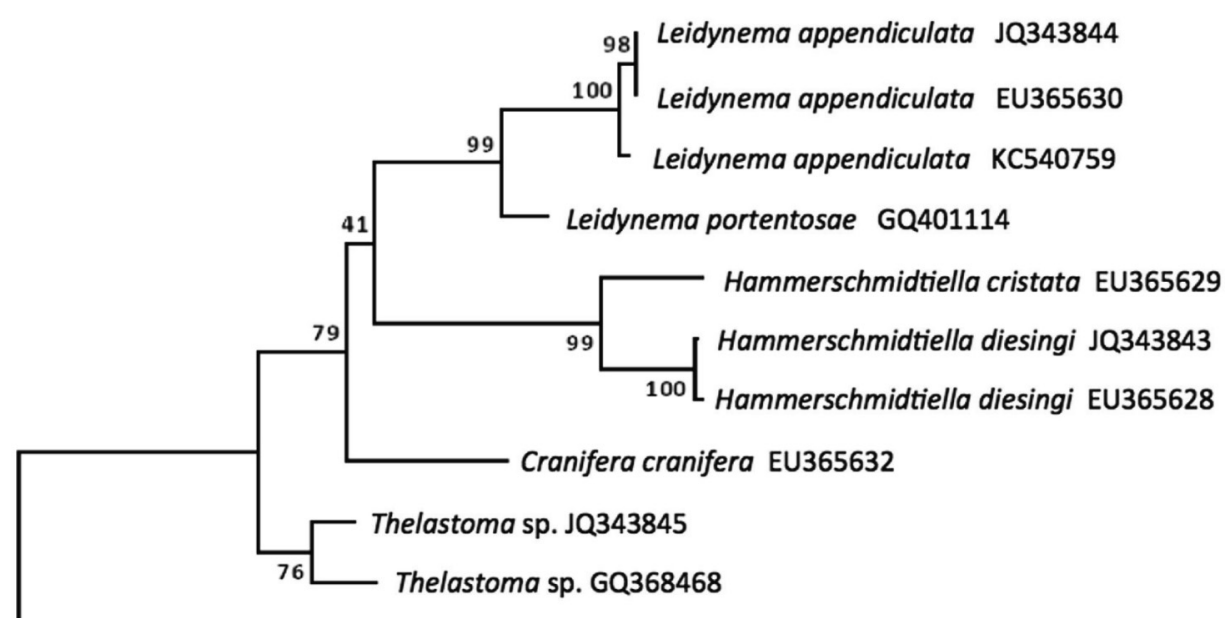

Ascaris lumbricoides AY210806

a1

Fig. 4. Phylogenetic position of the Leidynema appendiculata isolated from smokybrown cockroach (NCBI GenBank accession number KC540759). The optimal tree with the sum of branch length $=1.32525374$ is shown. The percentage of replicate trees in which the associated taxa clustered together in the bootstrap test (1000 replicates) are shown next to the branches (Felsenstein 1985). The tree is drawn to scale, with branch lengths in the same units as those of the evolutionary distances used to infer the phylogenetic tree. There were a total of 672 positions in the final dataset. Evolutionary analyses were conducted in MEGA5 (Tamura et al. 2011)
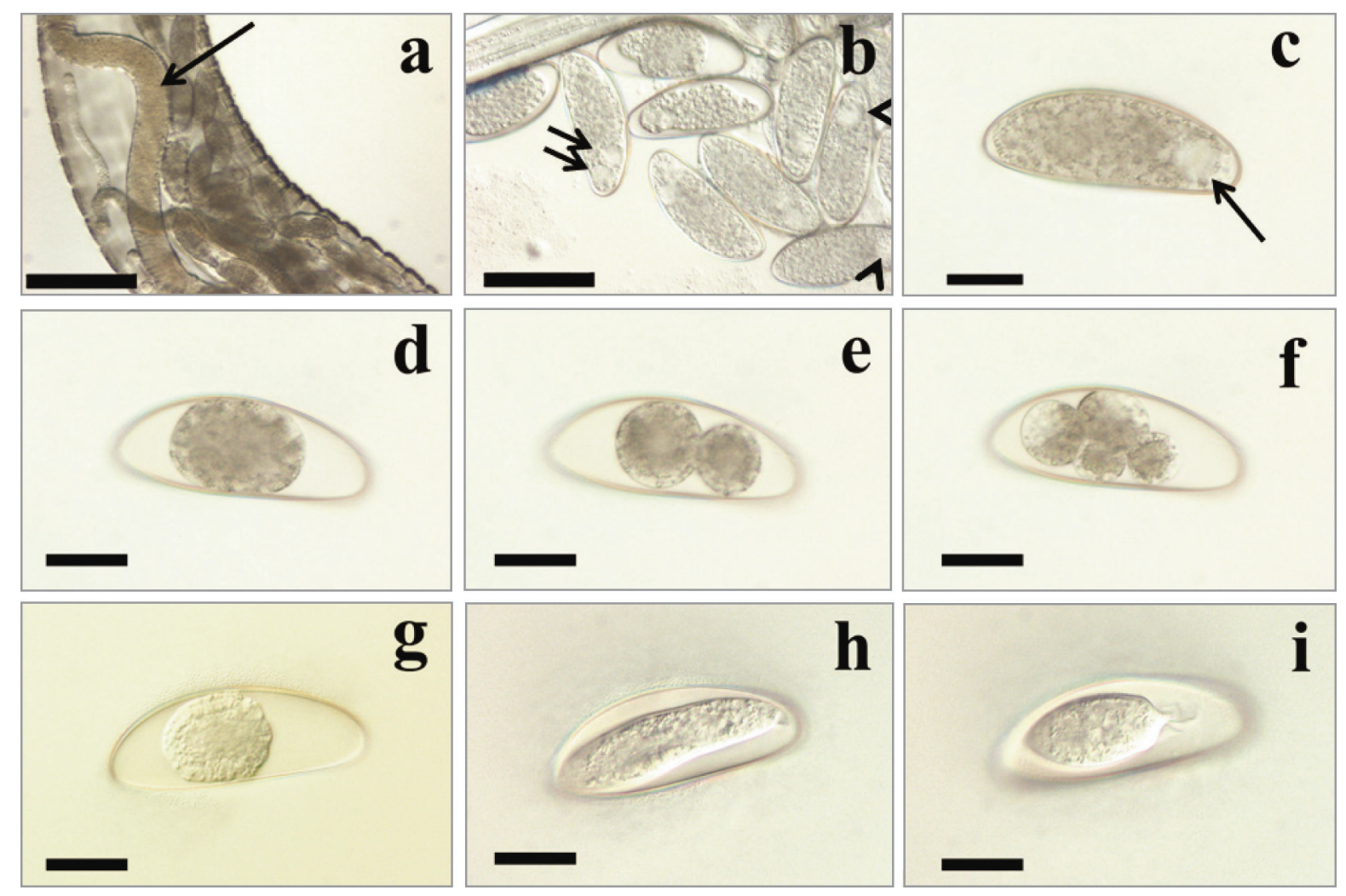

Fig. 5. Nomarski DIC image of L. appendiculata embryogenesis. (A) Embryos in the uterus. Arrow indicates the intestine. (B) Eggs spilled from the vulva. Some embryos had two pronuclei (arrows), but others had only one (arrowheads). (C) 1-cell stage embryo with one pronucleus (Arrow). Cytoplasm is spread in the egg. (D) 1-cell stage embryo. Pronucleus is disappeared and cytoplasm is condensed. (E) Two-cell stage embryo. (F) Four-cell stage embryo. (G) Many-cell stage, blastomeres are aggregated. (H) L1 sage. (I) L2 stage. Scale bars, (A), $200 \mu \mathrm{m} ;(\mathrm{B}), 100 \mu \mathrm{m} ;(\mathrm{C}-\mathrm{H}), 40 \mu \mathrm{m}$ 
Table III. Embryogenesis period from 1-cell stage embryo to 4-cell, L1 and L2 stage, collected from different egg conditions

\begin{tabular}{lccccc}
\hline & N & 2-cell & L-cell & L1 & L2 \\
\hline In fecus $^{1}$ & 8 & $4.6 \pm 1.7 \mathrm{~h}$ & $8.0 \pm 2.0 \mathrm{~h}$ & $2.9 \pm 0.8 \mathrm{~d}$ & $5.6 \pm 1.1 \mathrm{~d}$ \\
${\text { Ex } \text { uterus }^{1}}_{\text {In }_{\text {uterus }}}{ }^{1}$ & 10 & $2.5 \pm 1.4 \mathrm{~h}$ & $6.4 \pm 6.4 \mathrm{~h}$ & $6.9 \pm 2.7 \mathrm{~d}$ & $9.5 \pm 3.3 \mathrm{~d}$ \\
\hline
\end{tabular}

${ }^{1}$ All embryos in this data developed normally to reach L2 stage.

II). Male and female cockroaches and nematodes could not be sexed as larvae or juveniles.

At the average number of female nematodes in each individual cockroach was $3.5 \pm 6.3$ (ranging from 0 to 48 ) (Table II). With few exceptions, we usually found only one male per individual cockroach. No significant differences were observed in terms of the number of male nematodes between cockroach stages. Every cockroach was infected with some nematode juveniles at any age.

\section{Embryogenesis}

Adult $L$. appendiculata females isolated from $P$. fuliginosa contained many shell-formed eggs in the uterus (Fig. 5a). Almost all eggs were one-cell stage (Fig. 5b). A variety of developing stage embryos from undivided one-cell to late stage embryos were contained in the fresh feces of cockroaches.

First, cytoplasm of a one-cell embryo spread in the egg and contained one pronucleus at one pole (Fig. 5c). Some embryos had two pronuclei (Fig. 5b), but others had only one (Fig. 5b). Cytoplasm condensed gradually, and the pronucleus or paired pronuclei disappeared (Fig. 5d). Directed cytoplasmic streaming, pseudo-cleavage and dynamic male-female pronuclear meeting were not observed. The embryo divided unequally to form a larger cell and a smaller cell to form a two-cell stage (Fig. 5e). Next, the larger cell divided equally followed by the smaller cell to form a rhomboidal 4-cell stage (Fig. 5f). Blastomere number then increased via repeated cell division (Fig. $5 \mathrm{~g}$ ), followed by elongation and twitching (i.e., morphogenesis and organogenesis period). The pharynx and its grinder then became clearly visible, marking the beginning of the L1 stage (Fig. 5h). The active vermiform L1 stage embryo then molted to become a balloon-shaped resting L2 stage (Fig. 5i). All embryos that we observed were confirmed to reach the L2 stage successfully.

Table III shows the developmental rate of the L. appendiculata embryos collected by three methods; in feces, ex uterus, and in uterus. In feces and ex uterus embryos took, respectively, $4.6 \pm 1.7$ and $2.5 \pm 1.4$ hours from one-cell to 2 -cell stage and $8.0 \pm 2.0$ and $6.4 \pm 6.4$ hours to the 4-cell stage. In feces and ex uterus embryos took a total of $5.6 \pm 1.1$ days and $9.5 \pm 3.3$ days from one-cell to L2 stage, respectively. All in feces $(\mathrm{N}=8)$ and ex uterus $(\mathrm{N}=10)$ embryos developed normally to reach L2 stage. However, in uterus embryos took 5.0 \pm 11 days from the one-cell to the 2-cell stage and $29.7 \pm 7.42$ days to 4-cell stage. They had stayed as 2-cell stage for about
25 days and then re-start embryogenesis to the L2 stage. A total of 238 eggs were observed in three adult female uteri, from which 84 developed to L2 stage and the other 154 degraded before L2 stage.

\section{Discussion}

We dissected four Japanese strains of the smokybrown cockroaches that had been isolated and reared independently, and found that all were infected with only one nematode species, L. appendiculata. This is the first report of a thelastomatid nematode isolated from the smokybrown cockroach.

L. appendiculata is a cosmopolitan nematode species, which has been isolated from many Blattaria hosts, including P. americana, P. australasia and Blatta orientalis (Oriental cockroach) broadly known in the world as sanitary pests similar to P. fuliginosa (Todd 1944; Poinar 1975). In addition, Eurycotis floridana (Florida woods cockroach), Blaberus atropos, Hormetica scrobiculata, Blaptica sp. and Gromphadorhina portentosa (Madagascar hissing cockroach) were recently imported to Japan as pets or pet reptile foods, and also reported as L. appendiculata hosts (Poinar 1975; Blanco et al. 2012). Native habitats of these species (E. floridana, B. atropos, H. scrobiculata and Blaptica sp.) are located in Central and South America, but the origin and distribution route of the world traveling cockroaches are not clear. Because these cockroaches have $L$. appendiculata in common, it might mean that their origins are also common, or that this nematode has low host specificity. Both $H$. diesing $i$ and $L$. appendiculata co-parasitized a $P$. americana laboratory strain, but $L$. appendiculata couldn't survive during host molting (Hominick and Davey 1972). L. appendiculata might be able to re-infect easily when its hosts were reared at a high density in the laboratory. We did not observe any problems with $L$. appendiculata persisting through the $P$. fuliginosa molt (data not shown). This suggests that $P$. fuliginosa might be a more suitable host for L. appendiculata than P. americana. This nematode was also isolated from a non-cockroach insect (larvae of Oncideres sp., Cerambycidae beetle) (Stock 1988), and from lab reared Madagascar hissing cockroaches (Bhatnagar and Edwards, 1970). However, since these records are old, molecular data and clear pictures aren't left, revalidations are necessary.

There are reports of up to four thelastomatid nematodes coexisting (T. bulhoesi, T. periplaneticola, $H$. diesingi and L. appendiculata) in the gut of $P$. americana, with no evidence 
of interspecific competition (Connor and Adamson 1998; Adamson and Noble 1993; Hominick and Davey 1972). Multiple nematode species infection is common in cockroaches (Jex et al. 2005; Jex et al. 2006a,b), and we have isolated at least 15 unknown parasitic nematode species from the Japanese wood cockroach Panesthia angustipennis spadica, and also isolated two species (Thelastoma bulhoesi and $H$. diesingi) from the American cockroach P. americana from Japan (Ozawa and Hasegawa unpublished data). Here, we found that all of the four strains of smokybrown cockroaches from Japan were only infected by L. appendiculata. This cockroach might have been originally infected with multiple nematode species, but dropped other parasitic species except for L. appendiculata during dispersal. Arthropods living in ecologically similar niches share parasitic thelastomatid species (Jex et al. 2005; Jex et al. 2006a,b). If the communities of parasitic nematodes in the smokybrown cockroaches in the world are examined, we might be able to predict their origin.

Mean number of adult male nematodes in the cockroach gut was usually fixed to one, while the number of adult female nematodes was a few to many in female cockroaches. $L$. appendiculata juveniles were always present in any host age, probably because the egg supply and juvenile discharge may be continuously occurring to sustain an adult population in the cockroach hindgut in a lab culture. Nematode population regulation is found in other nematode species and almost always results in one or a few females (Hominick and Davey 1973; Zervos 1987; Zervos 1988a; Zervos 1988b; Zervos 1988c; Adamson and Noble 1993). The mechanism of the regulation is not clear, but is hypothesized to be regulated by the nematode itself (Zervos 1988a; Zervos 1988b). Population control of $L$. appendiculata was also observed in adult $P$. americana (Hominick and Davey 1972).

The first unequal cell division of the nematode embryo reveals the anterior-posterior axis formation of the body plan, whereas the larger cell is the future anterior pole, whereas the smaller cell is the future posterior region (Hasegawa et al. 2004; Yoshida et al. 2009). In Caenorhabditis elegans, the anterior-posterior axis is determined by the sperm-supplied centrosome, the actin cytoskeleton, and maternal elements such as cortical protein and cytoplasmic determinants (Galli and van den Heuvel 2008). The thelastomatid nematodes employ a haplo-diploid lifecycle (arrhenotoky) in which unfertilized eggs become males and fertilized eggs become females (Adamson et al. 1989; Adamson 1994). We also detected two types of $L$. appendiculata embryos; one type has two pronuclei that might develop to become female, and the other has only one pronucleus that might develops as meiotic or mitotic parthenogenesis to become male. We did not observe directed cytoplasmic streaming, pseudo-cleavage, or clear pronuclear behavior during the one-cell stage under the DIC microscopy. We might be able to reveal whether the male develops as meiotic parthenogenesis or mitotic parthenogenesis through the observation of chromosome structure and behavior during the $1^{\text {st }}$ cell stage (Hasegawa et al. 2006). The mechanism of the- lastomatid body axis determination, which must be different from that for C. elegans, is also in great need of further investigation.

The developmental timing of the nematode embryos collected in the different conditions was quite different especially the in uterus embryos which remained at the 2-cell stage for a long period. In sexually reproducing diploids, oocytes are arrested in the diakinesis stage in the germ cell, and complete meiosis and start development after fertilization (Hasegawa et al. 2006). Because L. appendiculata is haplodiploid and its embryo can develop without fertilization, some mechanism might arrest egg development during its stay in the uterus. After the parent died, its suppression might be weakened and eggs in the uterus are likely to start their development.

The well-balanced population structures of organisms in natural ecosystems are assembled over long periods of evolutionary time. Recent invasions of species through global economic activity have challenged this balance (Westphal et al. 2008). When alien species invade an environment, we must pay attention to the impact of its mutualistic or parasitic partners. Although the impact of a parasitic nematode to the original host may be small, it could be fatal in a new host. For example, the human pinworm Enterobius vermicularis only causes itching in the anal area of its native human host, but can be fatal in chimpanzees, Pan troglodytes (Murata et al. 2002). After the invasion of $P$. fuliginosa in Japan, the native cockroach P. japonica has been displaced. Research on the impact of the L. appendiculata against the Japanese cockroach seems to be of great value.

Acknowledgements. The smokybrown cockroaches were provided by Fuji Environmental Service (Shizuoka, Shizuoka Prefecture), Ikari Corporation (Chiba, Chiba Prefecture), Earth Environmental Service (Ako, Hyogo Prefecture). We thank to Dr. Keith P. Choe, University of Florida for useful comment on this manuscript. This work was supported by the Chubu University special research fund.

\section{References}

Adamson M. L., Clease D.F. 1989. Morphological changes during in ovo development in the Thelastomatoidea: description and functional considerations. Journal of Parasitology, 75, 728-734.

Adamson M.L., van Waerebeke D. 1992. Revision of the Thelastomatidea, Oxyurida of invertebrate hosts I. Thelastomatidae. Systematic Parasitology, 21, 21-63.

Adamson M.L., Noble S.J. 1993. Interspecific and intraspecific competition among pinworms in the hindgut of Periplaneta americana. Journal of Parasitology, 79, 50-56.

Adamson M.L. 1994. Evolutionary patterns in life histories of Oxyurida. International Journal for Parasitology, 24, 1167-1177.

Ainsworth R. 1991. Cytogenetic evidence of haplodiploidy in two species of nematode (Pharyngodonidae: Oxyurida) from New Zealand lizards. Journal of Parasitology, 77, 92-98. 
Appel A.G., Smith L.M.II. 2002. Biology and management of the smokybrown cockroach. Annual Reviews of Entomology, 47, 33-55. DOI: 10.1146/annurev.ento.47.091201.145106.

Asahina S. (Ed.) 1991. Blattaria of Japan. Nakayama Shoten, Tokyo, Japan, 253 pp.

Bhatnagar K.N., Edward L.J. 1970. Parasites of the Madagascar cockroach Gromphadorhina portentosa. Annals of the Entomological Society of America, 63, 620-621.

Bell W.J. (Ed.) 1981. The Laboratory Cockroach - Experiments in Cockroach Anatomy, Physiology and Behavior. Chapman \& Hall, London, UK, 161 pp.

Bell W.J., Roth L.M., Nalepa C.A. (Eds.) 2007. Cockroaches: ecology, behavior, and natural history. The Johns Hopkins University Press, Baltimore, Maryland, USA, $230 \mathrm{pp}$.

Blanco M.V., Lax P., Dueñas J.C.R., Gardenal C.N., Doucet M.E. 2012. Morphological and molecular characterization of the entomoparasitic nematode Hammarschmiditiella diesingi (Nematoda, Oxyurida, Thelastomatidae). Acta Parasitologica, 57, 302-310. DOI: 10.2478/s11686-012-0029-2.

Chitwood B. 1932. A synopsis of the nematodes parasitic in insects of the family Blattidae. Parasitology Research, 5, 14-50.

Connor S., Adamson M. 1998. Niche overlap among three species of pinworm parasitic in the hindgut of the American cockroach, Periplaneta americana. Journal of Parasitology, 84, $245-247$.

Dobrovolny C.G., Ackert J.E. 1934. The life history of Leidynema appendiculata (Leidy), a nematode parasite of cockroaches. Parasitology, 26, 468-480.

Felsenstein J. 1985. Confidence limits on phylogenies: An approach using the bootstrap. Evolution, 39, 783-791.

Galli M. van der Heuvel S. 2008 Determination of the cleavage plane in early C. elegans embryos. Annual Review of Genetics, 42, 389-411. DOI: 10.1146/annurev.genet.40.110405.09 0523

Grimaldi D., Engel M.S. (Eds.). 2005. Evolution of the insects. Cambridge University Press, Cambridge, UK, 772 pp.

Hall T.A. 1999. BioEdit: a user-friendly biological sequence alignment editor and analysis program for Windows 95/98/NT. Nucleic Acids Symposium Series, 41, 95-98.

Hasegawa K., Futai K., Miwa S., Miwa J. 2004. Early embryogenesis of the pinewood nematode Bursaphelenchus xylophilus. Development Growth and Differentiation, 46, 153-161. DOI: 10.1111/j.1440-169X.2003.00734.x.

Hasegawa K., Mota M.M., Futai K., Miwa J. 2006. Chromosome structure and behavior in Bursaphelenchus xylophilus (Nematoda: Parasitaphelenchidae) germ cells and early embryo.Nematology, 8, 425-434. DOI: 10.1163/15685410 6778493475.

Hominick W.M., Davey K.G. 1972. The influence of host stage and sex upon the size and composition of the population of two species of thelastomatids parasitic in the hindgut of Periplaneta americana. Canadian Journal of Zoology, 50, 947-954.

Hominick W.M., Davey K.G. 1973. Food and the spatial distribution of adult female pinworms parasitic in the hindgut of Periplaneta americana L. International Journal for Parasitology, 3, 759-771.

Jex A.R., Schneider M.A., Rose H.A., Cribb T.H. 2005. The Thelastomatoidea (Nematoda: Oxyurida) of two sympatric Panesthiinae (Insecta: Blattodea) from southeastern Queensland, Australia: taxonomy, species richness and host specificity. Nematology, 7, 543-575. DOI: 10.1163/156854105 774384741.

Jex A.R., Hu M., Rose H.A., Schneider T.H., Cribb T.H., Gasser R.B. 2006a. Molecular characterization of Thelastomatoidea (Nematoda: Oxyurida) from cockroaches in Australia. Par- asitology, 133, 123-129. DOI: http://dx.doi.org/10.1017/ S0031182006009978.

Jex A.R., Schneider T.H., Cribb T.H. 2006b. The importance of host ecology in thelastomatid (Nematoda: Oxyurida) host specificity. Parasitology International, 55, 169-174. DOI: 10.1016/j.parint.2006.03.001.

Kimura M. 1980. A simple method for estimating evolutionary rate of base substitutions through comparative studies of nucleotide sequences. Journal of Molecular Evolution, 16, 111-120. DOI: 10.1007/BF01731581.

Lee C.Y., Lee L.C. 2000. Influence of sanitary conditions on the field performance of chlorpyrifos-based baits against American cockroaches, Periplaneta americana (L.) (Dictyoptera: Blattdae). Journal of Vector Ecology, 25, 218-221.

Miller D.M., Meek F. 2004. Cost and efficacy comparison of integrated pest management strategies with monthly spray insecticide applications for German cockroach (Dictyoptera: Blattellidae) control in public housing. Journal of Economic Entomology, 97, 559-569.

Murata K., Hasegawa H., Nakano T., Noda A., Yanai T. 2002. Fatal infection with human pinworm, Enterobius vermicularis, in a captive chimpanzee. Journal of Medical Primatology, 31, 104-108. DOI: 10.1034/j.1600-0684.2002.01017.x.

Nunn G.B. 1992. Nematode molecular evolution. An investigation of evolutionary patterns among nematodes based upon DNA sequences. Ph. D. dissertation. University of Nottingham, UK

Ogata K., Tanaka I., Ogawa T. 1975. Studies on establishing factors of domiciliary cockroaches. 1. Field surveys of the distribution of domiciliary cockroaches in Tokyo and Kawasaki. Japanese Journal of Sanitary Zoology, 26, 241-245.

Poinar G.O. (Ed.). 1975. Entomogenous nematodes: a manual and host list of insect-nematode associations. Brill, Leiden, Netherland, $317 \mathrm{pp}$.

Saitou N., Nei M. 1987. The neighbor-joining method: A new method for reconstructing phylogenetic trees. Molecular Biological Evolution, 4, 406-425.

Shah M.M. 2007. Some studies on insect parasitic nematodes (Oxyurida, Thelastomatoidea, Thelastomatidae) from Manipur, North-East India. Acta Parasitologica, 52, 346-362. DOI: $10.2478 / \mathrm{s} 11686-007-0051-y$.

Shaham S. 2006. Methods in Cell Biology. In: The C. elegans Research Community (Ed.). WormBook, http://www.wormbook.org. DOI: doi/10.1895/wormbook.1.49.1,

Stock S.P. 1988. Leidynema (L.) appendiculata (Nematoda: Thelastomatidae) en larvas de Oncideres sp. (Coleoptera: Cerambycidae) en la Argentina. Revista Peruana de Entomología, 31, 151-153.

Tamura K., Peterson D., Peterson N., Stecher G., Nei M., Kumar S. 2011. MEGA5: Molecular Evolutionary Genetics Analysis using Maximum Likelihood, Evolutionary Distance, and Maximum Parsimony Methods. Molecular Biological Evolution, 28, 2731-2739. DOI: 10.1093/molbev/ msr121.

Todd A.C. 1944. On the development and hatching of the eggs of Hammerschmidtiella diesingi and Leidynema appendiculatum, nematodes of roaches. Transactions of the American Microscopical Society, 63, 54-67.

Wada-Katsumata A., Silverman J., Schal C. 2013. Changes in taste neurons support the emergence of an adaptive behavior in cockroaches. Science, 340, 972-975. DOI: $10.1126 / \mathrm{sci}-$ ence. 1234854 .

Westphal M.I., Browne A., MacKinnon K., Noble I. 2008. The link between international trade and the global distribution of invasive alien species. Biological Invasion, 10, 391-398. DOI: $10.1007 / \mathrm{s} 10530-007-9138-5$. 
Yoshida K., Hasegawa K., Mochiji N., Miwa J. 2009. Early embryogenesis and anterior-posterior axis formation in the white-tip nematode Aphelenchoides besseyi. Journal Nematology, 41, 17-22.

Zervos S. 1987. Protrellus dalei n. sp., Blatticola barryi n. sp., and Suifunema mackenziei n. sp., thelastomatid nematodes from New Zealand cockroaches. New Zealand Journal of Zoology, 14, 240-250. DOI: 10.1080/03014223.1987. 10422994.

Zervos S. 1988a. Population regulation in parasitic nematodes (Thelastomatidae) of cockroaches. New Zealand Journal of Zoology, 15, 333-338. DOI: 10.1080/03014223.1988. 10422622 .

Received: September 12, 2013

Revised: October 28, 2013

Accepted for publication: January 31, 2014
Zervos S. 1988b. Population dynamics of a thelastomatid nematode of cockroaches. Parasitology, 96, 353-368. DOI: http:// dx.doi.org/10.1017/S0031182000058340.

Zervos S. 1988c. Evidence for population self-regulation, reproductive competition and arrhenotoky in a thelastomatid nematode of cockroaches. Parasitology, 96, 369-379. DOI: http://dx.doi.org/10.1017/S0031182000058352. 